\title{
DIETARY CARNITINE MAINTAINS ENERGY RESERVES AND DELAYS FATIGUE OF EXERCISED AFRICAN CATFISH (Clarias gariepinus) FED HIGH FAT DIETS
}

\author{
Rodrigo Ozório1*; Vincent Van Ginneken²; Guido van den Thillart²; Martin Verstegen'; Johan \\ Verreth $^{1}$ \\ ${ }^{I}$ Wageningen Institute of Animal Science (WIAS), Wageningen University, PO Box 338 - 6700 AH Wageningen, \\ The Netherlands. \\ ${ }^{2}$ Institute of Ecological and Evolutionary Sciences, Integrative Zoology, PO Box 9511 - 2300 RA Leiden, The \\ Netherlands. \\ *Corresponding author <rodrigo.ozorio@cimar.org>
}

\begin{abstract}
Lipids, together with proteins, are traditionally considered as primary fuels during aerobic swimming. The effects of dietary fat and carnitine supplements and exercise on the energy metabolism of juvenile fish were investigated. One hundred African catfish (Clarias gariepinus) were fed four isonitrogenous diets containing a fat level of 100 or $190 \mathrm{~g} \mathrm{~kg}^{-1}$ diet and one of the two levels of carnitine ( 15 and $1000 \mathrm{mg} \mathrm{kg}^{-1}$ ). Fish grew from 61 to $162 \mathrm{~g}$ in $10 \mathrm{wk}$. Thereafter, 6 fish per group swam vigorously for $3 \mathrm{~h}$ and the results were compared with unexercised groups. Fish receiving 1,000 $\mathrm{mg}$ carnitine accumulated 2- to 3-fold more carnitine than fish receiving $15 \mathrm{mg}$ carnitine. Plasma acyl-carnitine level was affected by an interaction between dietary treatment and exercise $(P<0.05)$. Adenosine triphosphate and phosphocreatine concentrations were higher in the white muscle (WM) of exercised fish fed the highcarnitine supplements, compared with the low-carnitine fed fish $(P<0.05)$. Adenilate energy charge indexes were higher and ammonia concentrations were lower in WM of fish fed high-carnitine and highfat diets. Dietary carnitine supplements may be needed in growing fish when dietary lipid level is high. In that case extra dietary carnitine can maintain the body energy reserves at adequate level when fish is exposed to a short-term, exhaustive exercise, a physiologic stress common both in nature and in intensive aquaculture systems.
\end{abstract}

Key words: lipid metabolism, catfish, stress, intensive aquaculture, exhaustive swimming

\section{CARNITINA DIETÉTICA MANTEM RESERVAS ENERGÉTICAS E EVITA A FATIGA DE BAGRE-AFRICANO DURANTE EXERCÍCIO}

RESUMO: Lipídios e proteínas são tradicionalmente considerados combustíveis primários durante natação aeróbica. Nesse ensaio foi investigado o efeito da suplementação de vários níveis de gordura e carnitina no metabolismo de 100 bagres africanos juvenis (Clarias gariepinus). Os peixes foram arraçoados com quatro

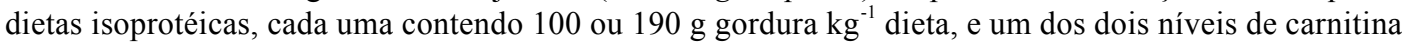
(15 e $\left.1000 \mathrm{mg} \mathrm{kg}^{-1}\right)$. Os peixes cresceram de 61 a $162 \mathrm{~g} \mathrm{em} 10$ semanas. No final do ensaio de alimentação, grupos de seis peixes por tratamento foram induzidos a nadar vigorosamente por $3 \mathrm{~h}$ e em seguida vários parâmetros foram determinados no tecido muscular e plasma, e os resultados observados nos grupos exercitados foram comparados com grupos controles (não exercitados). Os peixes arraçoados com 1,000 $\mathrm{mg}$ carnitina acumularam de duas a três vezes mais carnitina que os peixes arraçoados com $15 \mathrm{mg}$ carnitina. O nível de acyl-carnitina no plasma foi influenciado pela interação entre os tratamentos dietéticos e exercício físico $(P<0.05)$. As concentrações de adenosina trifosfato (ATP) e fosfocreatina no tecido muscular branco (WM) foram mais elevadas em peixes arraçoados com alto nível de carnitina dietética, mas só aqueles peixes exercitados $(P<0.05)$. Os peixes arraçoados com 190 g gordura e 1,000 mg carnitina obtiveram um nível elevado de potencial energético adenilado (AEC) e uma redução da concentração de amônia plasmática. A suplementação de carnitina dietética é importante para peixes criados em sistemas intensivos e em fase inicial de crescimento, uma situação típica que o consumo de gordura é elevado. A utilização de dietas ricas em carnitina poderá evitar que o animal vivencie uma redução brusca das reservas energéticas, durante períodos de atividade física exaustiva, um estresse fisiológico relativamente comum no habitat natural e em sistemas de aqüicultura intensiva.

Palavras-chave: metabolismo de lipídeo, bagre-africano, estresse, dinâmica nutricional, carnitina 


\section{INTRODUCTION}

High-energy phosphogens (i.e. phosphocreatine (Pcr) and adenosine triphosphate (ATP)) are the primary cellular energy source. Lipids represent an important source of high-energy phosphogens replenishment. Lipids, together with proteins, are traditionally considered as primary fuels during aerobic swimming (Cowey et al., 1962; Mommsen et al., 1980; Henderson \& Tocher, 1987). There are some indications of decreased lipid levels of white muscle after exhaustive exercise in rainbow trout (Milligan \& Girard, 1993; Wang et al., 1994).

Mitochondrial $\beta$-oxidation dominates in both red and white muscle tissues. In general, the red muscle possesses the highest fatty acid oxidation capacity. Considering that white muscle mass occupies approximately $60 \%$ of the total animal body weight, it could be an important tissue in the overall fatty acid catabolism.

As lipid requirement increases progressively during exercise, so does the requirement for certain components involved in lipid metabolism (Chatzifotis \& Takeuchi, 1997; Heo et al., 2000a; Ozório et al., 2003). During lipid catabolism ( $\beta$-oxidation), carnitine is required for the transfer of long-chain fatty acids from the cytosol to the mitochondrial matrix, and is involved in the transesterification and excretion of acyl-CoA esters. Carnitine is thus required for mitochondrial $\beta$-oxidation of fatty acids, a process that provides the cell with acetylCoA to fuel the Krebs cycle. Carnitine is synthesized in the liver from the amino acids lysine and methionine (Broquist, 1997).

Dietary carnitine is conditionally essential in young animals, including fish, (Heo et al. 2000a, 2000b). Furthermore, endogenous carnitine synthesis may not be sufficient either when lipid level is high or in adequacy of carnitine precursors in diet (Borum, 1983). The rate of cellular lipid oxidation is determined by the energy requirements of working muscles and by the availability of free-carnitine delivery to muscle mitochondria (Demmelmair et al., 1997; Gomes \& Tirapegui, 2000). Carnitine has an important role in exercise performance and lipid metabolism in mammals and birds (Souffleux, 1994; Janssens et al., 1998; Kraemer \& Volek, 2000; Sachan \& Hongu, 2000). However, little is known about the effects of dietary carnitine supplements on the energy metabolism of exercised fish.

This work hypothesizes that high-energy phosphogens (ATP) in white muscle of juvenile catfish are reduced during exhaustive exercise and that such body energy crisis can be alleviated by supplementing carnitine to the diets. In that case, the effect is observed only when oxidative carnitine requirement exceeds the endogenous carnitine synthesis, i.e. when fish are fed high-fat diets. To test this hypothesis, African catfish (Clarias gariepinus) juveniles were fed different levels of dietary fat and carnitine, for ten weeks, and then exposed to a short-term exhaustive exercise.

\section{MATERIAL AND METHODS}

\section{Fish and Husbandry}

Full-siblings African catfish with identical nutritional history were obtained from a commercial hatchery (Fleuren, Someren, The Netherlands). The experiment was approved by the Dutch Experimental Animal and Welfare Committee according to the EC Directive applied to vertebrate animals. Fish were kept in aquaria with a constant flow of $100 \%$ air-saturated water connected to a recirculation system. Aquaria used were glass aquaria $(70 \times 35 \times 40 \mathrm{~cm}), 70 \mathrm{~L}$ of water volume. Each aquarium was connected to a recirculation system with a total volume of $8.25 \mathrm{~m}^{3}, 25 \%$ water renewal per week, and with identical husbandry conditions.

\section{Experimental design and Diets}

One hundred juvenile African catfish $(61 \mathrm{~g} \pm 2.5$ g) were randomly divided into four treatment groups (25 fish per group). Each group as pre-conditionally fed with one of the four experimental diets at satiation for ten weeks. Diets were formulated to contain 100 or $190 \mathrm{~g} \mathrm{~kg}^{-1}$ fat and one of the two levels of carnitine: 15 or 1,000 $\mathrm{mg} \mathrm{kg}^{-1}$ (Table 1). To restrict carnitine biosynthesis, diets were formulated to contain low fishmeal level. Since the diets were isonitrogenous (337 $\mathrm{g} \mathrm{kg}^{-1}$ crude protein) changes in dietary fat levels were followed by concurrent changes in dietary carbohydrate. At the end of the feeding trial, fish (final individual weight $161.7 \pm 21.9 \mathrm{~g}$; body length (BL) $15 \mathrm{~cm}$ ) were fasted for five days and 12 fish were randomly selected from each group. Six fish swam for $3 \mathrm{~h}$ in a 100-L Blazka-type swimming tunnel, and were used to represent the exercised group. All fish were initially acclimated for $1 \mathrm{~h}$ to an exercise rate of $15 \mathrm{~cm} \mathrm{~s}^{-1}$. Following acclimation, the flow of water was increased to all groups equally, step-wise, by $11 \mathrm{~cm} \mathrm{~s}^{-1}$ every $60 \mathrm{~min}$ to achieve a final swimming speed of $37 \mathrm{~cm} \mathrm{~s}^{-1}$. All fish were able to maintain swimming at $37 \mathrm{~cm} \mathrm{~s}^{-1}$. The other six fish were also placed for $3 \mathrm{~h}$ into a swimming tunnel without exercise, and were used as the unexercised control. A constant flow of fresh water $\left(25^{\circ} \mathrm{C} ; 100 \%\right.$ air saturation $)$ was provided to all groups.

Water velocity was calculated by the following equation, elucidated earlier by Laser-Doppler techniques at the Hydraulics Laboratory TU, Delft (The Netherlands).

$$
\mathrm{V}=0.001307 \times \mathrm{R}-0.01724
$$

where: $\mathrm{V}=$ water velocity in meter per second; $\mathrm{R}=$ revolutions per minute of the engine of the Blazka swim tunnel.

The constants 0.001307 and 0.01724 are related to the size of the tunnel and motor. 
Table 1 - Diet ingredients and composition.

\begin{tabular}{|c|c|c|}
\hline Dietary fat $\left(\mathrm{g} \mathrm{kg}^{-1}\right)$ & 100 & 190 \\
\hline & \multicolumn{2}{|c|}{-...- $\mathrm{g} \mathrm{kg}^{1} \mathrm{dm}_{\text {basis }}$} \\
\hline Dietary carnitine $\left(\mathrm{mg} \mathrm{kg}^{-1}\right)$ & $15 / 1000$ & $15 / 1000$ \\
\hline \multicolumn{3}{|l|}{ Ingredients } \\
\hline Wheat meal & 133.7 & 213.0 \\
\hline Corn gluten meal & 183.7 & 314.0 \\
\hline Feathermeal & 102.0 & - \\
\hline Menhaden meal & 153.1 & 152.9 \\
\hline Chalk & 84.7 & 80.6 \\
\hline Capelin oil & 56.1 & 122.3 \\
\hline Durabon binder & 25.5 & 24.5 \\
\hline Pregelatinised maize starch & 255.1 & 86.6 \\
\hline Premix $^{a}$ & 5.1 & 5.1 \\
\hline L-Carnitine L-Tartrate ${ }^{\mathrm{b}}$ & $-/ 1.6$ & $-/ 1.6$ \\
\hline \multicolumn{3}{|l|}{ Analyzed nutrients } \\
\hline Dry matter & 983.9 & 983.4 \\
\hline Crude Protein & 335.9 & 339.2 \\
\hline Crude Fat & 106.9 & 190.0 \\
\hline Crude ash & 135.1 & 133.4 \\
\hline Carbohydrate $^{c}$ & 326.0 & 240.3 \\
\hline L-Carnitine & $0.014 / 0.97$ & $0.017 / 1.07$ \\
\hline Lysine $^{\mathrm{d}}$ & 13.3 & 13.8 \\
\hline Methionine $^{\mathrm{d}}$ & 7.2 & 9.8 \\
\hline $\mathrm{P} / \mathrm{E}\left(\mathrm{g} \mathrm{KJ}^{-1}\right)^{\mathrm{e}}$ & 17.4 & 16.7 \\
\hline
\end{tabular}

angredient supplied per kilogram of feed. Vitamins: Vitamin A, 2250010 IE; vitamin D, 250001 IE; vitamin E, 20001 IE. Minerals: $501 \mathrm{mg} \mathrm{CuSO} ; 15000 \mathrm{mg} \mathrm{ZnSO} ; 0.01 \mathrm{MnSO}_{4} ; 500 \mathrm{CoSO}_{4} ; 500$ $\mathrm{KI} ; 35 \mathrm{Na}_{2} \mathrm{SeO}_{3}$; ${ }^{\mathrm{b}} 67 \%$ purity, non-hygroscopic, heat stable, bright white crystalls (Lonza Group Ltd); ' gelatinized sugars and starch content; ${ }^{\mathrm{d}}$ Analyzed according to Ozório et al. (2002); ${ }^{\mathrm{e}}$ Protein-toenergy ratio.

\section{Sampling}

Blood sampling occurred $24 \mathrm{~h}$ before and immediately after the exercise for determination of plasma concentrations of free and esterified carnitine and ammonia. Fish were anesthetized with tricaine methane sulphonate [0.3 g TMS (Crescent Research Chemicals, Phoenix, AZ, USA) and $\left.0.4 \mathrm{~g} \mathrm{~L}^{-1} \mathrm{NaHCO}_{3} \mathrm{H}_{2} \mathrm{O}\right]$. Blood samples $(0.5 \mathrm{~mL})$ were collected from the caudal vein of each fish and centrifuged $\left(10 \mathrm{~min} ; 1,500 \times g ; 4^{\circ} \mathrm{C}\right)$. Plasma was then separated and stored at $-20^{\circ} \mathrm{C}$. After blood sampling, fish were killed by decapitation, white muscle tissue (WM) were sampled from the region between the dorsal fin and the lateral line, and immediately freeze-clamped between aluminum tongs cooled in liquid nitrogen. The freeze-clamped samples were stored at $-86^{\circ} \mathrm{C}$ pending analyses.

\section{White muscle extraction}

WM extractions for analyses of adenine nucleotide compounds (ATP, PCr, ADP and AMP), inosine monophosphate (IMP) and ammonia were carried out from a modified procedure of van Ginneken et al. (1999). Frozen tissue was powdered in an electrical morter (Retsch), cooled with liquid nitrogen together with 4.0 $\mathrm{mL}$ of perchloric acid $\left(8 \% \mathrm{vol} \mathrm{vol}^{-1}\right)$ in ethanol $(40 \% \mathrm{vol}$ vol $^{-1}$ ) containing $4 \mathrm{mmol} \mathrm{L}^{-1} \mathrm{NaF}$ and $10 \mathrm{mmol} \mathrm{L}^{-1}$ EDTA, and $46.6 \mathrm{mmol} \mathrm{L}^{-1}$ dUTP (dUTP sodium salt Sigma D 4001). The powder was stored for $10 \mathrm{~min}$ in a centrifuge tube cooled in liquid nitrogen. The homogenate was then stored for $30 \mathrm{~min}$ on ice and later centrifuged (Sorvall $\mathrm{RC}-5 \mathrm{~B}$ ) for $20 \mathrm{~min}$ at $30,000 \mathrm{~g}$. The supernatant was neutralized to $\mathrm{pH} 7.0$ with $3 \mathrm{~mol} \mathrm{~L}^{-1}$ potassium carbonate $\left(\mathrm{K}_{2} \mathrm{CO}_{3}\right)$ in 0.5 triethanolamine. Finally, the extracts were again centrifuged $(20 \mathrm{~min}$ at $30.000 \mathrm{~g}$ ) and the volume of the muscle supernatant was recorded and stored at $80^{\circ} \mathrm{C}$.

\section{Assays and measurements}

Ammonia concentrations were analyzed enzymatically (no. 171-UV, Sigma Aldrich, St. Louis, MO, USA) and determined using a $\mathrm{DU}^{\circledR}$ series 60 spectrophotometer (Beckman, Fullerton, CA, USA) at $340 \mathrm{~nm}$ wave length. Carnitine concentrations were determined in plasma and WM by radio-enzymatic assay with ${ }^{3} \mathrm{H}-\mathrm{la}-$ beled Acetyl-CoA as a substrate and mediated by the addition of Carnitine Acetyl Transferase (CAT) (Gustavsen, 2000). After the reaction was completed, the labeled acetyl-CoA was separated from the labeled acetyl-carnitine by anion exchange. The radioactivity of the latter was measured by liquid scintillation counting. In the present study, carnitine is represented as free- and acylcarnitine. The total carnitine content is the sum of both fractions.

The WM concentrations of the adenine nucleotide compounds and IMP were determined using High Liquid Performance Chromatography (LKB/PHARMACIA HPLC System). The energy status in the WM is expressed as the adenylate energy charge (AEC), where AEC = $([\mathrm{ATP}]+0.5[\mathrm{ADP}]) /([\mathrm{ATP}]+[\mathrm{ADP}]+[\mathrm{AMP}])$ (Atkinson, 1968). In exponentially growing cells, the AEC is $\sim 0.7$ to 0.9 , while in carbon source-starved cells, $\mathrm{AEC}$ is $<0.5$ (Chapman et al., 1971).

\section{Statistical Analyses}

All variables were tested by ANOVA for the effects of exercise (exercise vs. unexercised), dietary carnitine level (15 vs. $1,000 \mathrm{mg} \mathrm{kg}^{-1}$ ) and dietary fat level (100 vs. $\left.190 \mathrm{~g} \mathrm{~kg}^{-1}\right)$. Differences between means were reported as significant if $(P<0.05)$. All statistical analyses were performed using SAS program (SAS, 1999).

\section{RESULTS}

Plasma carnitine concentrations were increased by 2-fold as an effect of dietary high-carnitine supplements (Figure 1a; $P<0.05$ ). An interaction between di- 
etary treatments and exercise were observed on the level of plasma circulating acyl-carnitine $(P<0.05)$. High-carnitine feeding quadruplicated the total carnitine concentrations in white muscle (WM) (Figure $1 \mathrm{~b}, P<0.05$ ). Moreover, WM free-carnitine concentrations were affected by the carnitine and fat interaction $(P<0.05)$, but were not affected by exercise alone.

Figure $2 \mathrm{a}$ and $2 \mathrm{~b}$ show the effects of dietary treatment and exercise on ammonia concentrations on plasma and WM, respectively. Plasma ammonia concentration were reduced when fish were fed on dietary high-fat level $(P<0.05)$. However, plasma ammonia was not affected by dietary carnitine level and/or exercise (Figure 2a). Dietary carnitine supplementation affected the WM ammonia concentration $(P<0.01)$ only in exercised fish fed the high dietary fat (Figure 2b). Regarding AEC index, interactions between dietary treatment and exercise were observed (Figure 3, $P<0.05$ ). In exercised fish, AEC was positively correlated with carnitine and fat levels in the diet, but only at high fat level. AEC was $45 \%$ lower in fish fed the high-fat and low-carnitine diet, in comparison to the high-fat and high-carnitine fed fish (0.51 vs. $0.92, P<0.005)$. The reduction of the AEC was associated particularly with the decrease in ATP (Table 2). Furthermore, the $\mathrm{PCr}$ concentrations increased and the IMP concentration decreased with high-carnitine feeding.
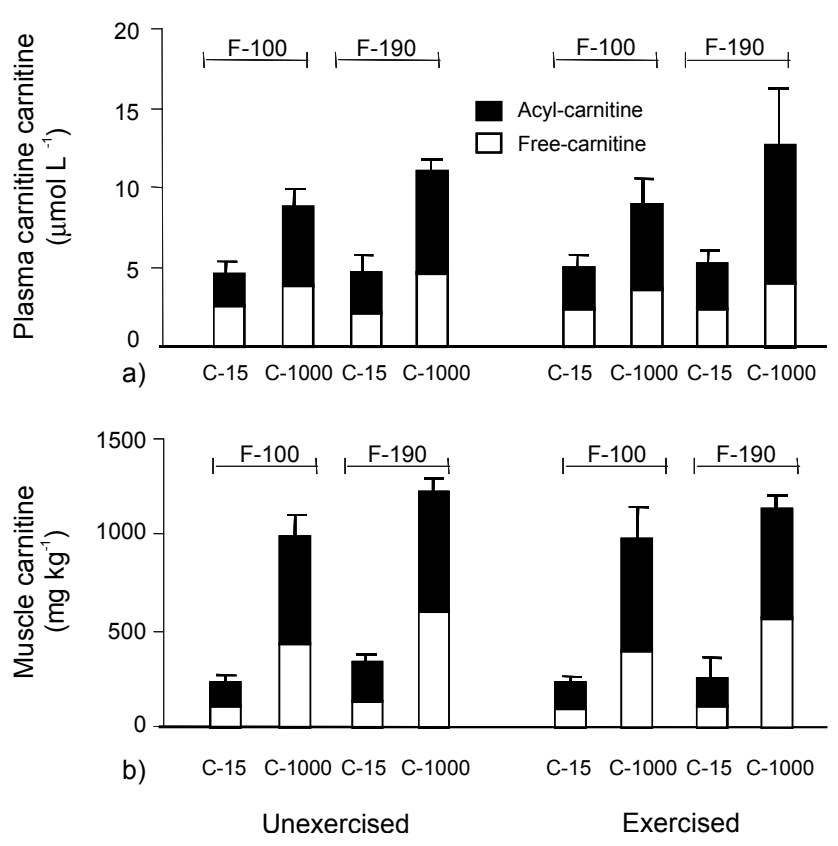

Figure 1 - Effect of dietary carnitine and fat levels in the (a) plasma and (b) white muscle free- (ם) and esterified- ( $\square$ ) carnitine of exercised juvenile African catfish, compared with unexercised control fish. F-100, $100 \mathrm{~g}_{\text {fat }} \mathrm{kg}^{-1}$ diet; $\mathrm{F}-190,190 \mathrm{~g}$ fat $\mathrm{kg}^{-1}$ diet; C-15, $15 \mathrm{mg}$ carnitine $\mathrm{kg}^{-1}$ diet; $\mathrm{C} 1000,1000 \mathrm{mg}$ carnitine $\mathrm{kg}^{-1}$ diet. Data is presented as mean \pm SD.

\section{DISCUSSION}

African catfish was chosen as a model species because it is a robust fish, with rapid growth and a closing live-cycle. In addition, its well-documented nature of body composition enables proper evaluation of the results.
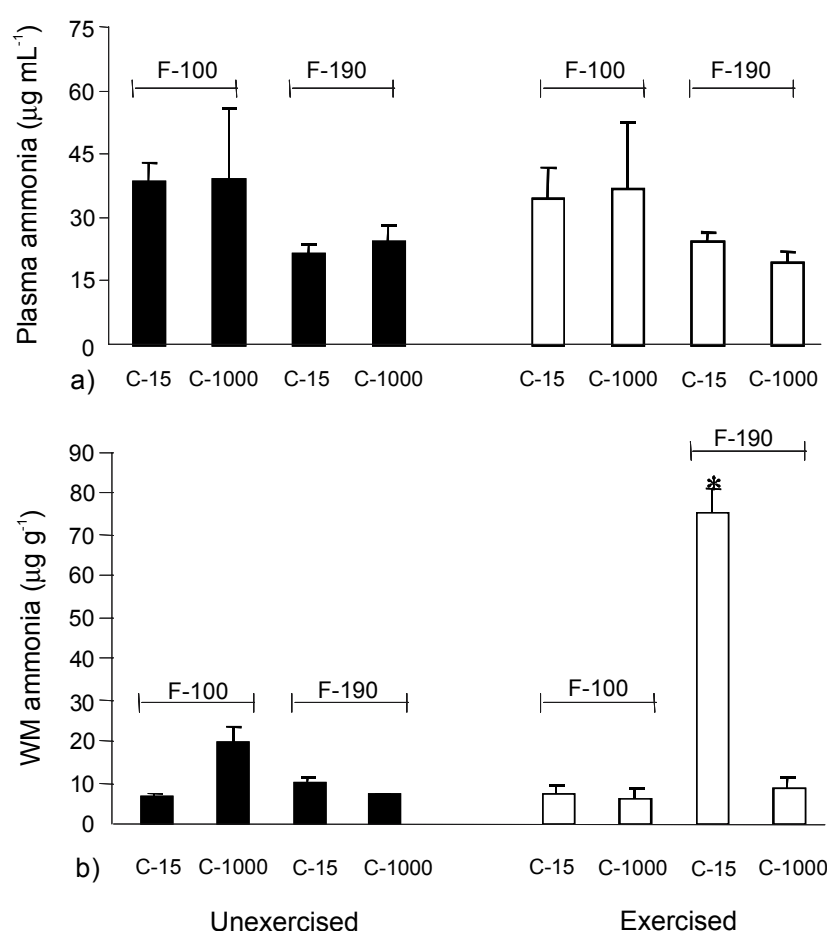

Figure 2 - Effect of dietary carnitine and fat levels in the (a) plasma and (b) white muscle ammonia of exercised juvenile African catfish ( $\square$ ), compared with unexercised control fish (匹). F-100, $100 \mathrm{~g}$ fat $\mathrm{kg}^{-1}$ diet; F-190, $190 \mathrm{~g}$ fat $\mathrm{kg}^{-1}$ diet; C-15, $15 \mathrm{mg}$ carnitine $\mathrm{kg}^{-1}$ diet; $\mathrm{C} 1000,1000 \mathrm{mg}$ carnitine $\mathrm{kg}^{-1}$ diet. Data is presented as mean $\pm \mathrm{SD} ;\left(^{*}\right)$, significantly different $(P<0.05)$.

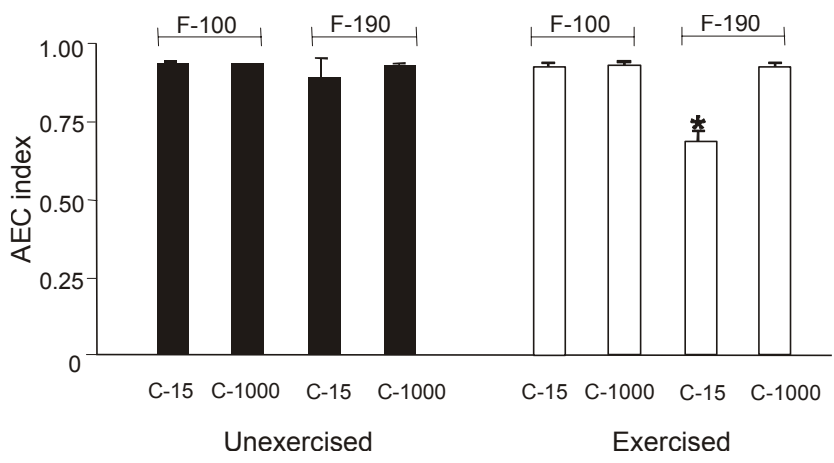

Figure 3 - Effect of dietary carnitine and fat levels in the white muscle adenilate energy charge (AEC) of exercised juvenile African catfish ( $\square$ ), compared with unexercised control fish (匹). F-100, $100 \mathrm{~g}_{\text {fat }} \mathrm{kg}^{-1}$ diet; F-190, $190 \mathrm{~g}$ fat $\mathrm{kg}^{-1}$ diet; C-15, $15 \mathrm{mg}$ carnitine $\mathrm{kg}^{-1}$ diet; C1000, $1000 \mathrm{mg}$ carnitine $\mathrm{kg}^{-1}$ diet. Data is presented as mean \pm $\mathrm{SD} ;\left(^{*}\right)$, significantly different $(P<0.05)$. 
Table 2 - Mean values $(n=6)$ of the effect of dietary carnitine and fat supplements on the $\mathrm{PCr}^{1}, \mathrm{ATP}^{2}$ and IMP $\mathrm{IM}^{3}$ levels in white muscle of exercised African catfish, compared with control unexercised fish ( $\left.\mathrm{mmol} \mathrm{L}^{-1}\right)$

\begin{tabular}{|c|c|c|c|c|c|c|c|c|c|}
\hline \multirow{3}{*}{$\begin{array}{l}\text { fat }\left(\mathrm{g} \mathrm{kg}^{-1}\right) \\
\text { carnitine }\left(\mathrm{mg} \mathrm{kg}^{-1}\right)\end{array}$} & \multicolumn{4}{|c|}{ Unexercised } & \multicolumn{4}{|c|}{ Exercised } & \multirow[t]{3}{*}{ SEM } \\
\hline & \multicolumn{2}{|c|}{100} & \multicolumn{2}{|c|}{190} & \multicolumn{2}{|c|}{100} & \multicolumn{2}{|c|}{190} & \\
\hline & 15 & 1000 & 15 & 1000 & 15 & 1000 & 15 & 1000 & \\
\hline $\mathrm{PCr}$ & 62.0 & 54.1 & 51.7 & 45.9 & 47.5 & 52.6 & $4.6^{*}$ & 39.9 & 13.5 \\
\hline ATP & 7.4 & 6.9 & $3.9 *$ & 7.2 & 6.9 & 7.2 & ND* & 7.0 & 1.5 \\
\hline IMP & ND & ND & ND & ND & ND & ND & 6.3 & ND & - \\
\hline ANOVA & $\mathrm{C}$ & $\mathrm{F}$ & $\mathrm{E}$ & $\mathrm{CxF}$ & $\mathrm{CxE}$ & FxE & $\mathrm{CxFxE}$ & & \\
\hline $\mathrm{PCr}$ & 0.2 & 0.006 & 0.0003 & 0.04 & 0.006 & 0.06 & 0.08 & & \\
\hline ATP & 0.06 & 0.003 & 0.35 & 0.005 & 0.17 & 0.33 & 0.005 & & \\
\hline IMP & 0.009 & 0.009 & 0.01 & 0.009 & 0.01 & 0.01 & 0.01 & & \\
\hline
\end{tabular}

*Different (ANOVA, $P<0.05$ ). ND, below detection limit.

${ }^{1}$ Phosphocreatine; ${ }^{2}$ Adenine triphosphate; ${ }^{3}$ Inosine monophosphate. $\mathrm{C}=$ carnitine; $\mathrm{F}=$ fat; $\mathrm{E}=$ exercise.

High-carnitine groups accumulated more free- and acyl-carnitine in the plasma and WM tissue than low-carnitine groups, regardless of exercise. This suggests that dietary carnitine was absorbed and entered intermediary metabolism. Moreover, total carnitine levels tended to be higher at high fat levels. Changes in the amount of total carnitine may be correlated with changes in the carnitine requirement. In humans and terrestrial animals, plasma carnitine concentration is higher after a high-fat diet (Stadler et al., 1993; Heo et al., 2000b; Greenwood et al., 2001), possibly because of an increase in carnitine reabsorption. In fish, plasma and tissue carnitine concentrations has also been suggested to be positively correlated with dietary fat (Gaylord \& Gatlin, 2000). It is reasonable to postulate that more carnitine may be needed by the animal for the metabolism of the excess of dietary lipid.

The increase in the acyl-carnitine fraction may be derived from stimulated $\beta$-oxidation of excess fatty acids. These finding are in close agreement with Ozório et al. (2003) who observed a reduction in the long-chain fatty acid concentration in African catfish fed high-carnitine diets. In the present study, dietary low-carnitine compared with high-carnitine feeding induced an increase in the ammonia concentration in the WM of exercised fish, but only at high-fat level. The latter effect may be associated with the dietary carnitine effect on the ATPand PCr levels. Under aerobic conditions, ammonia originates mainly in the liver by transdeamination and the hydrolysis of imino groups, while an additional quantity is formed in working skeletal muscles by the deamination of adenylates (Mommsen \& Hochachka, 1988; Wright et al., 1988; Wang et al., 1994). Elevated ammonia levels are thought to block the malate-aspartate shuttle (Hindfelt et al., 1977). This metabolic block would have a feedback inhibition on the PCr and ATP-generating pathway (Table 2). Under condition of extreme exercise, the main function of $\mathrm{PCr}$ is to buffer the ATP pool in the cell by the creatine kinase equilibrium reaction. When $\mathrm{PCr}$ in the white muscle is depleted during exercise (Schulte et al., 1992) to approximately $20 \%$ or less, the ATP pool is no longer stabilized and the ATP concentration declines. In this case, the normalization of the muscle ammonia by dietary carnitine supplementation would indirectly improve the energy metabolism of the animal. In fish fed low-carnitine diets, PCr and ATP levels were depleted from the white muscle during exercise. When carnitine was supplemented to the diets, energy levels remained at pre-exercise levels. In that case, the effect was observed only when oxidative carnitine requirements exceeded the endogenous carnitine synthesis, i.e. during high-fat feeding.

It has been generally accepted that aerobic swimming activity is often powered by the catabolism of endogenous and dietary lipids. If carnitine is not readily available, lipids are absorbed in insufficient amounts. In that case, fish will have to burn protein, instead of fat, to sustain muscle activity. Therefore, higher cumulative ammonia concentration observed in fish fed low-fat diets can be attributable to an increase in muscle protein breakdown, triggered by its precondition carnitine deficiency. Considering such, high-carnitine supplements may have prevented protein from being catabolized by increasing the flow of fatty acids though the TCA cycle, thus increasing the "protein-sparing action". It is intriguing, however, that the low-fat treatment fish were able to maintain muscle ammonia during exercise at low levels, as were the high-fat and high-carnitine exercised fish. It is plausible to speculate that could there be energetic substrate differences related to preferential use of glycolytic substrates in the low-fat exercised fish.

Plasma and tissue carnitine levels are positively correlated with dietary carnitine supplementation. In addition, extra dietary carnitine can enhance fatty acid oxidation, accounted by increased plasma acyl-carnitine lev- 
els, in exercised fish when fish is fed high-fat level. Accordingly, ATP levels and AEC values are increased and ammonia levels are lowered.

\section{Implications}

Addition of carnitine to aquafeeds, few weeks before inducing any physical stress, could potentially alleviate problems experienced by intensive farmed fish, which generally consume high-fat diets. Such strategy might increase survival rates and decrease nitrogen emission to the environment. Moreover, it will promote the wellbeing of the cultured species by decreasing stress-related aspects in intensive aquaculture practices.

\section{REFERENCES}

ATKINSON, D.E. Energy charge of the adenylate pool as a regulatory parameter. Interactions with feedback modifiers. Biochemistry, v.7, p.4030-4034, 1968.

BORUM , P.R. Carnitine. Annual Review of Nutrition, v.3, p.233-259, 1983.

BROQUIST, H.P. Memories of microbes and metabolism. Annual Review of Nutrition, v.17, p.1-18, 1997.

CHAPMAN; A.G.; FALL, L.; ATKINSON, D.E. Adenylate energy charge in Escherichia coli during growth and starvation. Journal of Bacteriology v.108, p.1072-1086, 1971.

CHATZIFOTIS, S.; TAKEUCHI, T. Effect of supplemental carnitine on body weight loss, proximate and lipid compositions and carnitine content of Red Sea bream (Pagrus major) during starvation. Aquaculture, v.158, p.129-140, 1997.

COWEY, C.B.; DAISLEY, K.W.; PARRY, G. Study of amino acids, free or as components of protein and some B vitamins in the tissues of the Atlantic salmon, Salmo salar, during spawning migration. Comparative Biochemistry and Physiology, v.7, p.29-38, 1962.

DEMMELMAIR, H.; SAUERWALD, T.; KOLETZKO, B.; RICHTER, T. New insights into lipid and fatty acid metabolism via stable isotopes. European Journal of Pediatrics, v.156, p.S70-S74, 1997.

GAYLORD, T.G.; GATLIN, D.M. Dietary lipid level but not L-carnitine affects growth performance of hybrid striped bass (Morone chrysops $\mathrm{x}$ M. saxatilis). Aquaculture, v.190, p.237-246, 2000.

GOMES, M.D.; TIRAPEGUI, J. Relation of some nutritional supplements and physical performance. Archivos Latinoamericanos de Nutricion, v.50, p.317-329, 2000 .

GREENWOOD, R.H.; TITGEMEYER, E.C.; STOKKA, G.L.; DROUILLARD, J.S.; LOEST, C.A. Effects of L-carnitine on nitrogen retention and blood metabolites of growing steers and performance of finishing steers. Journal of Animal Science, v.79, p.254-260, 2001.

GUSTAVSEN, H.S.M. Bestimmung des Carnitingehaltes in rohen und zubereiteten pflanzlichen und tierischen Lebensmitteln (in German). Hannover: School of Veterenary Medicine, 2000. (Doctoral thesis).

HENDERSON, R.J.; TOCHER, D.R. The lipid composition and biochemistry of freshwater fish. Progress in Lipid Research, v.26, p.281-347, 1987.

HEO, K.N.; ODLE, J.; HAN, I.K. Effects of dietary L-Carnitine and protein level on plasma carnitine, energy and carnitine balance, and carnitine biosynthesis of $20 \mathrm{~kg}$ pigs. Asian-Australian Journal of Animal Science, v.13, p.1568-1575, 2000a.

HEO, K.N.; LIN, X.; ODLE, J.; HAN, I.K. Kinetics of carnitine palmitoyltransferase-I are altered by dietary variables and suggest a metabolic need for supplemental carnitine in young pigs. Journal of Nutrition, v.130, p.2467-2470, 2000b.
HINDFELT, B.; PLUM, F.; DUFFY, T.E. Effect of ammonia intoxication on cerebral metabolism in rats with portacaval shunts. Journal of Clinical Investigation, v.59, p.386-396, 1977.

JANSSENS, G.P.J.; BUYSE, J.; SEYNAEVE, M.; DECUYPERE, E.; DE WILDE, R.. The reduction of heat production in exercising pigeons after L-Carnitine supplementation. Poultry Science, v.77, p.578-584, 1998.

KRAEMER, W.J.; VOLEK, J.S. L-Carnitine supplementation for the athlete a new perspective. Annals of Nutrition and Metabolism, v.44, p.8889, 2000.

MILLIGAN, C.L.; GIRARD, S.S. Lactate metabolism in rainbow trout. Journal of Experimental Biology, v.180, p.175-193, 1993.

MOMMSEN, T.P.; HOCHACHKA, P.W. The purine nucleotide cycle as two temporally separated metabolic units: a study on trout muscle. Metabolism, v.37, p.552-556, 1988.

MOMMSEN, T.P.; FRENCH, C.J.; HOCHACHKA, P.W. Sites and patterns of protein and amino acid utilization during the spawning migration of salmon. Canadian Journal of Zoology, v.58, p.1785-1799, 1980.

OZÓRIO, R.O.A.; BOOMS, G.H.R.; HUISMAN, E.A.; VERRETH, J.A.J. Changes in amino acid composition in the tissues of African catfish (Clarias gariepinus) as a consequence of dietary L-carnitine supplements. Journal of Applied Ichthyology, v.18, p.140-147, 2002.

OZÓRIO, R.O.A.; VERRETH, J.A.J.; ARAGÃO, C.R.; VERMEULEN, C.J.; SCHRAMA, J.W.; VERSTEGEN, M.W.A. Evaluation of dietary carnitine supplements on plasma metabolite indices and fatty acid composition in African catfish (Clarias gariepinus) juveniles. Journal of Aquaculture in the Tropics, v.18, p.225-238, 2003.

SACHAN, D.S.; HONGU, N. Increases in VO2max and metabolic markers of fat oxidation by caffeine, carnitine, and choline supplementation in rats. Journal of Nutritional Biochemistry, v.11, p.521-526, 2000.

SAS INSTITUTE INC. SAS user's guide: Statistics (Version 6.). CARY: SAS Institute, 1999.

SCHULTE, P.M.; MOYES, C.D.; HOCHACHKA, P.W. Integrating metabolic pathways in the post-exercise recovery of white muscle. Journal of Experimental Biology, v.166, p.181-195, 1992.

SOUFFLEUX, G. Benefit of using Rossovet carnitine for horses in preparation for amateur carriage-racing. Pratique Veterinaire Équine, v.26, p.241-248, 1994.

STADLER, D.D.; CATHERINE, A.C.; REBOUCHE, C.J. Effect of dietary macronutrient content on carnitine excretion and efficiency of carnitine reabsorption. American Journal of Clinical Nutrition, v.58, p.868$872,1993$.

van GINNEKEN, V.J.T.; van de THILLART, G.E.E.J.M.; MULLER, H.J., van DEURSEN, S.; ONDERWATER, M.; VISE, J.; HOPMANS, V.; van VLIET, G.; NICOLAY, K. Phosphorylation state of red and white muscle in tilapia during graded hypoxia: an in vivo 31P-NMR study. American Journal of Physiology - Regulatory Integrative and Comparative Physiology, v.277, p.R1501-R1512, 1999.

WANG, Y.; HEIGENHAUSER, G.J.F.; WOOD, C.M. Integrated responses to exhaustive exercise and recovery in rainbow trout white muscle: Acidbase, phosphogen, carbohydrate, lipid, ammonia, fluid volume and electrolyte metabolism. Journal of Experimental Biology, v.195, p.227259, 1994.

WRIGHT, P.A.; RANDALL, D.J.; WOOD, C.M. The distribution of ammonia and $\mathrm{H}^{+}$between tissue compartments in lemon sole (Parophrys vetulus) at rest, during hypercapnia and following exercise. Journal of Experimental Biology, v.136, p.149-175, 1988.

$\overline{\text { Received August }}$ 27, 2004 Accepted February 15, 2005 